\title{
Actor and Partner Effects of Mothers' and Fathers' Parenting Stress and Family Cohesion and Flexibility on Warm Parenting Behavior
}

\author{
Yea-Ji Hong ${ }^{1}$, Soon-Hyung $\mathrm{Yi}^{1,2}$ \\ Department of Child Development and Family Studies, Seoul National University, Seoul Korea ${ }^{1}$ \\ Research Institute of Human Ecology, Seoul National University, Seoul, Korea ${ }^{2}$ \\ 유아 자녀를 둔 어머니와 아버지의 양육스트레스, 가족 응집성과 유연성 \\ 및 온정적 양육행동 간의 자기효과 및 상대방효과 검증 \\ 홍예지 $\left.\right|^{1}$, 이순형 1,2 \\ 서울대학교 아동가족학과 ${ }^{1}$, 서울대학교 생활과학연구소 ${ }^{2}$
}

Objective: The purpose of this study was to assess actor and partner effects of mothers' and fathers' parenting stress and family cohesion and flexibility on warm parenting behavior.

Methods: The sample consisted of 1,471 couples from the Panel Study of Korean Children. The sample was drawn from the sixth wave of data collection, including mothers and fathers of children aged 60-66 months. Data were analyzed via actor-partner interdependence models.

Results: The findings illustrated that the actor effect of parenting stress on warm parenting behavior was significant in mothers and fathers, but there was no partner effect. They also revealed that actor and partner effects were significant in relation to mothers' and father's parenting stress and family cohesion and flexibility. Moreover, there was an actor effect of family cohesion on warm parenting behavior for mothers and fathers, but its partner effect was significant only in mothers. Finally, the mediating effects of family cohesion and flexibility between parenting stress and warm parenting behavior was verified.

Conclusion: The results highlight not only the need for dyadic data analysis for mothers and fathers but also the need to consider in depth the fathers' role in parenting. Additional implications are discussed.

Keywords: parenting stress, family cohesion and flexibility, warm parenting behavior, actor effects, partner effects

\begin{abstract}
서론
가정에서 부모가 자녀를 양육하면서 느끼는 심리 상태와 가족 의 기능 및 부모의 양육행동은 아동의 건강한 성장과 발달을 도모하는 주요 변인이다. 아이는 부모와의 관계를 통해 주변

Corresponding Author: Soon-Hyung Yi, Department of Child Development and Family Studies, Seoul National University, 1 Kwanak-ro, Kwanak-gu, Seoul, 08826, Republic of Korea

E-mail: ysh@snu.ac.kr
\end{abstract}

의 사물에 대해 배우고, 이러한 부모와의 지속적인 상호작용 의 경험은 아이가 한 인간으로서 성장할 수 있는 전반적인 발 달의 기저가 되기 때문이다. 자녀 양육이 부부의 공동의 책임 으로 인식되는 탈 가부장적 관점으로 변화해가면서 주 양육자 인 어머니뿐만 아니라 유아기 아동의 자녀 양육과 교육에 긍

(C)The Korean Association of Child Studies

This is an Open Access article distributed under the terms of the Creative Commons Attribution Non-Commercial License (http:// creativecommons.org/licenses/by-nc/4.0) which permits unrestricted noncommercial use, distribution, and reproduction in any medium, provided the original work is properly cited. 
정적 영향을 미치는 아버지 효과에 대한 인식이 높아지고 있 다(Lee, 2015). 그러나 이러한 개인과 사회적 인식의 변화에도 불구하고 가정 내의 가사와 양육에의 아버지의 참여는 저조하 다. Statistics Korea (2015)는 가족가치관 중 가사분담의 항목에 대해 이는 전적으로 또는 주로 부인 책임이다(39.6\%)라는 응 답이 전적으로 또는 주로 남편 책임이다(1.6\%)라는 응답보다 월등이 높음을 보고하였다. 아내와 남편이 공평하게 분담해야 한다는 의견이 $59.3 \%$ 로 세대가 변화하면서 남편의 가정 내 돌 봄 및 참여에 대한 인식이 높아짐에도 불구하고 여전히 많은 부분 가정 내 어머니의 역할이 아버지 보다 더 강조됨을 알 수 있다. 배우자의 지지는 가정을 꾸려나가고 자녀를 양육함에 있어 느끼는 어려움과 부정적인 경험을 극복할 수 있는 힘이 된다. 다시 말해 가족이 기능적 역할을 할수록 가족 구성원이 보다 안정적인 심리상태를 유지하는데 도움을 주어 부정적 상 황을 더 원활하게 극복할 수 있다는 것이다.

부모의 양육행동은 자녀를 양육하면서 부모가 보이는 일반 적이고 보편적인 행동으로 부모-자녀 관계의 질을 결정하고, 심리·정서적 요인(Silver, Heneghan, Bauman, \& Stein, 2006) 및 환경적 요인(Raikes \& Thompson, 2005)에 영향을 미친다. 이와 관련하여 국내외 연구자들에게 많은 관심을 받고 있는 주요 변인으로 양육스트레스가 있다(Eom, Park, Doh, \& Nichiwaki, 2014; Silver et al., 2006; Zhang, Cubbin, \& Ci, 2016). 아이를 양 육함에 있어 부모로서의 양육의 책임과 역할은 새로운 가족 구성원을 길러내는 생산적인 과정인 동시에 스트레스를 유발 해 양육행동에 부적인 영향을 준다는 것이다.

양육스트레스란 가정 내에서 기대되는 부모로서의 역할 이 과중하거나 스스로가 유능하지 않다고 지각하는 과정에 서 느끼는 어려움, 짜증, 성가심 등의 감정을 모두 포함한다 (Mulsow, Caldera, Pursley, Reifman, \& Huston, 2002; Zhang et al., 2016). 이러한 일상적 스트레스는 주요한 생활사건(life event)보다 개인의 심리적 안녕과 적응을 보다 잘 예측하는 것 (Kanner, Coyne, Schaefer, \& Lazarus, 1981)으로 유아기 자녀 를 둔 부모에게 강하게 나타난다(Seginer, Vermulst, \& Gerris, 2002). Abidin (1992)은 양육스트레스와 양육행동 모델에서 두 변인의 영향력을 검증하였다. 즉, 주 양육자가 지각하는 낮은 양육스트레스는 자녀와의 의사소통 수준을 높이며 보다 온정 적인 양육행동을 수반하는 반면, 높은 양육스트레스는 통제적 이고, 권위적인 행동과 같은 부정적인 양육행동을 야기한다 (Choi \& Yeon, 2014; Ponnet et al., 2013). 특히 양육스트레스의 수준은 자신만이 아닌 배우자의 양육스트레스가 더해져 나타 날 수 있음을 주목하여야 할 것이다(Ponnet et al., 2013; Zhang et al., 2016).

한 가정 내의 어머니와 아버지가 지각하는 양육스트레스는 매우 비슷한 패턴을 보일 것이라는 선행연구(Deater-Deckard $\&$ Scarr, 1996)를 토대로 양육 환경에서 아버지 역할의 중요성 을 고려해 볼 필요가 있다. 구체적으로, 어머니가 지각한 아버 지의 양육참여가 높을수록 어머니의 양육스트레스 발생빈도 와 강도가 낮아졌다(Ponnet et al., 2013). 이와 같이 양육 환경 에서의 아버지의 적극적인 참여는 유아의 성장과 발달뿐만 아 니라 전반적인 가족의 기능에도 기여함을 예측할 수 있다. 그 러나 양육스트레스와 양육행동 간의 관계를 밝힌 연구는 대부 분 어머니만을 대상으로 하고 있거나 아버지와 분리된 분석 을 하였다는데 한계가 있다(Ponnet et al., 2013; Yeon, Yoon, \& Choi, 2016). 즉, 아버지 자신이 지각한 양육스트레스를 배우 자로부터 받는 양육스트레스와 분리하여 각각의 개별적인 측 면에 초점을 맞추어 분석하고 있어 어머니와 아버지 서로의 영향력을 확인한 연구는 활발하게 이루어지지 않고 있다.

이와 관련하여 아버지의 양육행동에 미치는 양육관련 변 인의 상대적 영향력을 탐색한 연구를 살펴보면, G. Y. Kim과 Shin (2013)의 연구는 아버지가 인지한 양육스트레스가 온정 적이고, 격려하는 행동에 유의한 영향을 미치지 않았다. Choi 와 Yeon (2014)의 연구는 평균 38.25개월인 유아기 자녀를 둔 어머니와 아버지 모두에게서 자신의 양육스트레스는 자신의 긍정적 양육행동에 부적으로 유의한 영향을 미쳐 두 변인 간 자기효과가 존재함을 밝혔다. 그러나 어머니의 양육스트레스 가 아버지의 긍정적 양육행동 또는 아버지의 양육스트레스가 어머니의 긍정적 양육행동에 미치는 두 변인 간 상대방 효과 는 유의미하지 않았다. 이상의 결과를 토대로 양육스트레스와 긍정적 양육행동 간의 관계에서 어머니 또는 아버지의 영향에 대한 단선적인 이해를 넘어서 서로의 상호 보완적 영향을 탐 색할 필요가 있다. 일반적으로 어머니와 아버지 각자의 양육 스트레스는 자신의 양육행동에 역기능적 요인임을 알 수 있으 나 이는 반드시 가족의 부적응을 초래하거나 자녀의 전반적인 발달을 저해하는 것은 아닐 것이다. 즉, 가족 응집성과 유연성 은 부모의 양육스트레스를 낮추고 온정적인 양육행동으로의 변화를 도모할 수 있는 보호요인임을 예측할 수 있다.

Olson, Russell과 Sprenkle (1983)의 순환모델은 가족 응집성 과 유연성을 측정하는 대표 모델로 가족 구성원의 유대감과 자율성의 균형을 강조하였다. 가족에 대한 소속감 및 정서적 유대감과 적절한 수준의 독립된 개인의 자율성이 균형을 이 룰 때 가정 내 유연한 대처가 가능하다는 것이다. 구체적으로, 가족의 기능은 가족 응집성과 가족 유연성으로 구분된다. 가 
족 응집성은 가족 구성원 간의 정서적 유대감을 의미하며, 가 족 유연성은 가족 구성원이 가족으로부터 또는 외부로부터 받 는 스트레스 상황에 직면할 때 적절하게 변화할 수 있는 능력 을 의미한다(Olson, Gorall, \& Tiesel, 2007). 가족 응집성과 유 연성은 가족 내에서 구성원이 경험하는 정서적 연결과 지지의 수준으로 개념화 될 수 있는데(Olson et al., 1983) 어머니와 아 버지 모두에게서 배우자의 양육스트레스가 높을수록 자신이 지각하는 가족 응집성이 낮았다(Mitchell, Szczerepa, \& HauserCram, 2016). 특히 가족의 기능은 개인의 심리적 특성과 밀접 한 관련이 있다. Ko와 $\mathrm{Kim}$ (2000)의 연구는 높은 수준의 가족 응집성과 가족 유연성이 기혼 남성 및 여성의 심리적.신체적 디스트레스와 같은 정신 및 신체 건강을 설명하는 유의미한 변인이라고 밝혔다. 이는 장애를 가진 아동을 양육하는 가정 (Mitchell \& Hauser-Cram, 2009)뿐만 아니라 일반 아동을 양육 하는 대부분의 가정(Shigeto, Mangelsdorf, \& Brown, 2014)에서 일반적으로 나타난다. 이를 기반으로 유아를 둔 가정의 가족 기능에 대한 연구가 지속적으로 수행될 필요가 있다.

가족 응집성과 유연성은 부모의 긍정적인 양육행동에 영 향을 미친다. 즉, 가족의 응집성과 유연성이 높은 수준에서 유 지될 때 부모는 권위 있는 양육행동을 보이는 반면 낮은 수준 에서 유지될 때 부모는 독재적인 양육행동을 보이는 경향이 있다(Matejevic \& Jovanovic, 2014). 비슷한 맥락에서 Yeon 등 (2016)의 연구는 유아 자녀를 둔 어머니와 아버지 모두에게 서 자신이 지각한 높은 수준의 가족 응집성과 유연성은 자신 의 긍정적 양육행동에 유의한 영향을 미쳐 두 변인 간 자기효 과가 존재함을 밝혔다. 그러나 상대방 효과는 조금 다른 경향 을 보였다. 어머니가 지각한 가족 응집성과 유연성은 아버지 의 긍정적 양육행동에 유의미한 정적 영향을 미쳤으나 아버지 가 지각한 가족 응집성과 유연성은 어머니의 긍정적 양육행동 에 유의미한 영향을 미치지 않았다. 지각된 가족 응집성과 유 연성의 수준이 자신 또는 상대방의 양육행동에 미치는 영향을 파악한 연구는 위의 연구를 제외하고는 전무한 실정으로 이에 대한 심도 있는 논의가 요구된다.

지금까지 살펴본 것처럼 양육행동에 영향을 미치는 변인인 양육스트레스 및 가족 응집성과 유연성에 대한 선행 연구는 대부분 어머니와 아버지를 개별적으로 분석하고 있다. 그러나 부부는 서로 의미 있는 상대방이며 양방향적인 영향을 미치는 관계이다(Yeon \& Choi, 2015). 이렇게 서로 영향을 주고받는 비독립적인 특성이 있는 남편과 아내의 자료를 분석할 때 짝 자료라는 점을 고려하지 않고 개별적으로 분석하게 되면 1종 오류를 범할 확률이 증가(Kenny, 1996)할 뿐만 아니라 서로 간
의 영향에 대한 타당한 결론에 이끌어내기에는 한계가 있다. 이에 따라 본 연구에서는 유아를 둔 어머니와 아버지의 양육 스트레스가 온정적 양육행동에 미치는 영향을 살펴보고, 가족 응집성과 유연성이 두 변인 간의 유력한 매개 역할을 할 것이 라 가정하였다. 기존의 연구에서 다루지 못했던 짝 자료의 특 징을 고려할 수 있는 연구 모형을 설정하여 어머니와 아버지 를 한 단위로 보고 각 변인 간의 관계에서 자기효과와 상대방 효과를 확인하고자 한다. 또한 자기효과와 상대방효과 간 상 대적 효과를 비교 검증하여 어머니와 아버지의 상호 간의 영 향력을 확인하고자 한다. 이를 바탕으로 도출된 연구문제는 다음과 같다.

\section{연구문제 1}

유아 자녀를 둔 어머니와 아버지의 양육스트레스가 온정적 양육행동에 미치는 영향의 자기효과와 상대방효과는 어떠한 가?

\section{연구문제 2}

유아 자녀를 둔 어머니와 아버지의 양육스트레스가 가족 응 집성과 유연성에 미치는 영향의 자기효과와 상대방효과는 어 떠한가?

\section{연구문제 3}

유아 자녀를 둔 어머니와 아버지의 가족 응집성과 유연성이 온정적 양육행동에 미치는 영향의 자기효과와 상대방효과는 어떠한가?

\section{연구문제 4}

유아 자녀를 둔 어머니와 아버지의 양육스트레스와 온정적 양육행동의 관계에서 가족 응집성과 유연성의 매개효과는 어 떠한가?

\section{연구방법}

\section{연구대상}

본 연구는 Korea Institute of Child Care and Education (KICCE; 2013)에서 2013년 실시한 한국아동패널(Panel Study on Korean Children [PSKC])의 6차 연도 자료를 활용하였다. 자기-상대 방 상호의존모형을 적용하기 위하여 어머니와 아버지가 모두 
설문의 각 변인에 응답한 경우만 분석에 포함하였고, 이를 위 해 완전제거 방식으로 결측치를 제거하였다. 최종적으로 부부 1,471 쌍이 포함되었다. 선행연구(Ponnet et al., 2013)에서 사회 경제학적 변인인 부모의 교육수준과 월 평균 가구소득이 부모 의 양육과 밀접한 관련이 있음을 확인한 후, 어머니와 아버지 양육스트레스의 통제변인으로 설정하였다. 월 평균 가구소득 의 경우 편포에 따른 문제를 해결하기 위해 로그값으로 변환 하여 분석모형에 투입하였다.

본 연구의 연구대상의 주요 사회.인구학적 특성을 간략하 게 살펴보면 다음과 같다. 분석 대상인 아버지의 연령은 만 $38.52(S D=3.97)$ 세, 어머니의 연령은 만 $36.10(S D=3.63)$ 세, 자녀의 연령은 만 $62.61(S D=1.31)$ 개월, 자녀의 성별은 남아 가 754 (51.3\%)명, 여아가 717 (48.7\%)명이었다. 교육수준은 아버지의 경우 대졸이 $42.6 \%$ 로 가장 많았고, 고졸이 $27.1 \%$ 로 뒤를 이었다. 전문대졸 $19.6 \%$, 대학원졸 $10.3 \%$, 중졸 이하 $0.5 \%$ 로 나타났다. 어머니의 경우 대졸이 $37.5 \%$ 로 가장 많았 고, 고졸이 $29.8 \%$ 로 뒤를 이었다. 전문대졸 $27.1 \%$, 대학원졸 $5.2 \%$, 중졸 이하 $0.4 \%$ 로 나타났다. 월 평균 가구 소득은 300 만원 이하 $32.9 \%, 300$ 만원 초과 500 만원 이하 $46.8 \%, 500$ 만원 초과 700 만원 이하 $13.9 \%, 700$ 만원 초과 1000 만원 이하 $5.7 \%$, 1000 만원 초과 $0.7 \%$ 에 해당하였다.

\section{연구도구}

\section{양육스트레스}

한국아동패널의 어머니와 아버지의 양육스트레스는 K. H. Kim과 Kang (1997)이 한국형으로 개발한 양육스트레스 척도 (Parenting Stress Index-Short Form)를 통해 수집되었다. 총 11 문항으로 구성되었으며 모두 5점 리커트 척도(1: 전혀 그렇 지 않다 5: 매우 그렇다)로 측정되었고, 점수가 높을수록 응 답자가 자녀를 양육하는 과정에서 경험하는 어려움, 부담감 과 같은 스트레스의 수준이 높음을 의미한다. 어머니 양육스 트레스의 Cronbach's $\alpha$ 는 .874이며, 아버지 양육스트레스의 Cronbach's $\alpha$ 는 .866으로 만족스러운 수준이었다.

\section{가족응집성과 유연성}

가족 응집성과 유연성은 Olson (2010)의 척도에서 한국아동패 널의 연구진이 응집성 및 유연성의 문항을 인출하여 재구성 한 척도를 통해 수집되었다. 가족 응집성과 유연성 각각 7 문항
으로 구성되며, 모두 5점 리커트 척도(1: 전혀 그렇지 않다 5: 매우 그렇다)로 측정되어 점수가 높을수록 가족 응집성과 유 연성의 수준이 높음을 의미한다. 어머니의 가족 응집성과 유 연성 Cronbach's $\alpha$ 는 .913이며, 아버지의 가족 응집성과 유연 성 Cronbach's $\alpha$ 는 .914로 만족스러운 수준이었다.

\section{온정적 양육행동}

한국아동패널조사의 온정적 양육행동은 Cho, Lee, Lee와 Kwon (1999)의 척도의 문항을 참고하여 연구진이 재구성한 척도를 통해 수집되었다. 총 8문항으로 모두 5점 리커트 척도 (1: 전혀 그렇지 않다 5: 매우 그렇다)로 측정되었고, 점수가 높을수록 반응적이고 온정적인 양육행동의 수준이 높음을 의 미한다. 어머니 온정적 양육행동의 Cronbach's $\alpha$ 는 .848이며, 아버지 온정적 양육행동의 Cronbach's $\alpha$ 는 .881로 만족스러운 수준이었다.

\section{자료분석}

본 연구에서는 SPSS 22.0 (IBM Co., Armonk, NY)과 AMOS 22.0 (IBM Co., Armonk, NY)을 사용하여 다음과 같은 방법으 로 분석하였다. 먼저 연구대상의 특성 및 분포를 파악하기 위 해 기술통계 및 상관분석을 실시하였다. 다음으로 구조방정 식의 자기-상대방 상호의존모형(Actor-Partner Interdependence Models [APIM])을 이용하여 변인 간 자기효과(actor effect)와 상대방효과(partner effect)를 확인하였다. 이와 같은 방법은 쌍 을 이루는 두 사람 간에 각 변인이 자기 또는 상대방에게 미치 는 상호의존적인 영향을 통합하여 측정하고, 확인할 수 있게 하는 통계적 기법이다(Cook \& Kenny, 2005). 이를 통해 자신 의 심리적 특성이나 행동이 자신 스스로에게 미치는 효과인 자기효과와 자신의 심리적 특성이나 행동이 상대방에게 미치 는 효과인 상대방효과를 각각 검증할 수 있다. 예를 들어, 남편 과 아내가 한 쌍인 커플 자료에서 아내의 어떤 요인이 남편의 어떤 반응을 예측하고, 남편의 어떤 요인이 아내의 어떤 반응 을 예측하는 가를 동시에 살펴보는 것이 가능하다.

또한 APIM을 활용하면 두 사람 간에 자기효과와 상대방 효과의 상대적 크기 차이를 비교할 수 있는데 이렇게 자신의 영향과 상대방의 영향을 비교하는 것은 부부 관계의 상호 영 향력을 더 정확하게 이해하는데 도움이 된다(Cook \& Kenny, 2005). 마지막으로 양육스트레스가 온정적 양육행동에 미치 는 영향에서 가족 응집성과 유연성의 매개효과를 확인하기 위 
Table 1

Descriptive Statistics and Correlation Coefficients Among Variables

\begin{tabular}{lcccccc}
\hline & 1 & 2 & 3 & 4 & 5 & 6 \\
\hline 1 & - & & & & & \\
2 & $.431^{* * *}$ & - & & & & \\
3 & $-.440^{* * *}$ & $-.208^{* * *}$ & - & & & \\
4 & $-.259^{* * *}$ & $-.450^{* * *}$ & $.321^{* * *}$ & - & - & - \\
5 & $-.410^{* * *}$ & $-.295^{* * *}$ & $.418^{* * *}$ & $.388^{* * *}$ & - & \\
6 & $-.277^{* * *}$ & $-.446^{* * *}$ & $.270^{* * *}$ & $.530^{* * *}$ & $.586^{* * *}$ & 3.874 \\
$M$ & 2.645 & 2.439 & 3.683 & 3.615 & 0.785 & -505 \\
SD & 0.617 & 0.602 & 0.537 & 0.626 & 0.536 & -0.688 \\
Skewness & 0.037 & 0.020 & -0.091 & -0.210 & 1.829 \\
Kurtosis & 0.102 & -0.071 & 0.217 & 0.439 & 1.857 & 1.829 \\
\hline
\end{tabular}

Note. $N=1,471$ couples. 1 = mothers' parenting stress; 2 = fathers' parenting stress; 3 = mothers' warm parenting behavior; 4 = fathers' warm parenting behavior; 5 = mothers' family cohesion and flexibility; 6 = fathers' family cohesion and flexibility.

${ }^{* * *} p<.001$.

해 Sobel test를 실시하였다. 어머니와 아버지의 양육스트레스 의 통제변인으로 설정한 교육수준과 월 평균 가구소득 및 각 변수 간의 오차 공분산은 모형의 간명함을 위해 모든 모형에 서 생략하였다.

측정변인 중 양육스트레스와 온정적 양육행동의 경우 요인 구조가 뚜렷이 나타나지 않아 전체문항을 임의할당방법을 사 용하였다. 이에 두, 세 개의 요인에 속하는 문항의 평균을 산출 하여 지표변인을 생성하였다. 가족 응집성과 유연성은 두 개 의 각각의 하위척도 요인을 그대로 이용하여 각 요인에 속하 는 문항의 평균을 사용하였다. 변인 간의 구조적 관계를 밝히 기에 앞서 양육스트레스, 가족 응집성과 유연성 및 온정적 양 육행동의 하위 측정 요인이 잠재변인을 적절하게 구인하는지 검증하기 위하여 확인적 요인분석을 실시하였다. 모형의 적합 도를 평가하기 위해서는 $\chi^{2}$ 값과 함께 절대적합지수인 RMSEA (Root Mean Square Residual)와 상대적 적합지수인(Tucker-Lewis Index) 및 CFI (Comparative Fit Index) 값을 종합적으로 고려하 였다. RMSEA의 경우 .06이하, TLI 및 CFI는 .90이상인 경우를 좋은 적합도로 보았다(Hu \& Bentler, 1999). 모형의 적합도는 $\chi^{2}=447.447(d f=62, p<.001), \mathrm{CFI}=.967, \mathrm{TLI}=.951$, RMSEA $=.060$ 으로 요인구조가 내적으로 타당함을 확인하였다. 또한 각 잠재변인에 속한 측정 요인의 요인부하량의 경우 절댓값 이 .40 이상의 경우 유의하다고 판단하는데(Song, 2015), 잠재 변인에서 측정 요인으로의 표준화된 회귀계수 값이 .750이상 .922 이하였다. C.R.값 또한 .001 수준에서 모두 유의하였다. 이 상의 결과를 통해 각 측정 요인이 해당 잠재변인의 개념을 잘
설명하며, 구성타당도가 확보되었음을 알 수 있다.

\section{연구결과}

\section{주요 변인의 기술 통계 및 상관분석}

본 연구에서 사용된 변인의 평균, 표준편차, 왜도, 첨도 및 Pearson 상관분석 결과는 Table 1에 제시하였다. 자료의 정규 성 확인을 위하여 각 변인별 왜도 및 첨도를 살펴본 결과, 왜도 의 절댓값이 2 미만, 첨도의 경우 4 미만인 것으로 나타나 본 자료가 정상분포의 조건을 충족시킨다(Hong, Malik, \& Lee, 2003). 상관분석 결과 어머니의 양육스트레스와 아버지의 양 육스트레스 간에 유의한 정적 상관이 있으며, 어머니의 양육 스트레스는 어머니의 온정적 양육행동, 아버지의 온정적 양육 행동, 어머니의 가족 응집성과 유연성 및 아버지의 가족 응집 성과 유연성에는 모두 부적으로 유의한 상관을 보였다. 아버 지의 양육스트레스는 어머니의 온정적 양육행동, 아버지의 온 정적 양육행동, 어머니의 가족 응집성과 유연성 및 아버지의 가족 응집성과 유연성에 모두 부적으로 유의한 상관이 있었 다. 어머니의 온정적 양육행동은 아버지의 온정적 양육행동, 어머니의 가족 응집성과 유연성 및 아버지의 가족 응집성과 유연성과 정적으로 유의한 상관을 보였으며, 아버지의 온정적 양육행동 역시 어머니의 가족 응집성과 유연성 및 아버지의 가족 응집성과 유연성과 모두 정적으로 유의한 상관관계가 나 
타났다. 어머니의 가족 응집성과 유연성은 아버지의 가족 응 집성과 유연성과 정적으로 유의한 상관을 보였다.

\section{양육스트레스가 온정적 양육행동에 미치는 자기효과와 상대방효과 검증}

부모의 교육수준과 월 평균 양육스트레스에 미치는 영향을 통 제한 후 양육스트레스가 온정적 양육행동에 미치는 자기효과 와 상대방효과를 검증하였다. 모형의 적합도는 $\chi^{2}=334.791$ $(d f=55, p<.001), \mathrm{CFI}=.964, \mathrm{TLI}=.949, \mathrm{RMSEA}=.054$ 로 모 형이 분석 자료를 적절히 설명하였다. 부모의 교육수준 $(\beta=$ $-.120, p<.01)$ 과 월 평균 가구소득 $(\beta=-.121, p<.001)$ 은 어머 니의 양육스트레스에 유의한 영향을 미쳤으며, 부모의 교육수 준 $(\beta=-.121, p<.01)$ 과 월 평균 가구소득 $(\beta=-.102, p<.01)$ 은 아버지의 양육스트레스에도 유의한 영향을 미쳤다.

양육스트레스는 온정적 양육행동에 부적인 영향을 미쳤 는데 자기효과만 유의하고 상대방 효과는 유의하지 않았다 (Figure 1). 양육스트레스의 자기효과와 상대방효과의 크기를 상대적으로 비교하기 위해 총 4 번의 등가제약 모형을 순서대 로 설정하였다. 첫 번째로 설정된 제약 모형 $(\mathrm{a}=\mathrm{b})$ 을 통해 양 육스트레스가 온정적 양육행동에 미치는 어머니와 아버지의 자기효과 비교가 가능하며, 두 번째로 설정한 제약 모형 $(\mathrm{c}=\mathrm{d})$ 으로 양육스트레스가 온정적 양육행동에 미치는 어머니와 아 버지의 상대방효과의 비교가 가능하다. 세 번째로 설정한 제 약 모형 $(\mathrm{a}=\mathrm{d})$ 을 통해 어머니의 온정적 양육행동에 미치는 양 육스트레스의 자기효과와 상대방효과를 비교할 수 있으며, 네 번째로 설정한 제약 모형 $(\mathrm{b}=\mathrm{c})$ 으로 아버지의 온정적 양육행 동에 미치는 양육스트레스의 자기효과와 상대방효과의 비교 가 가능하다. 순서대로 설정한 네 번의 등가제약 모형의 분석 결과는 Table 2 와 같다.

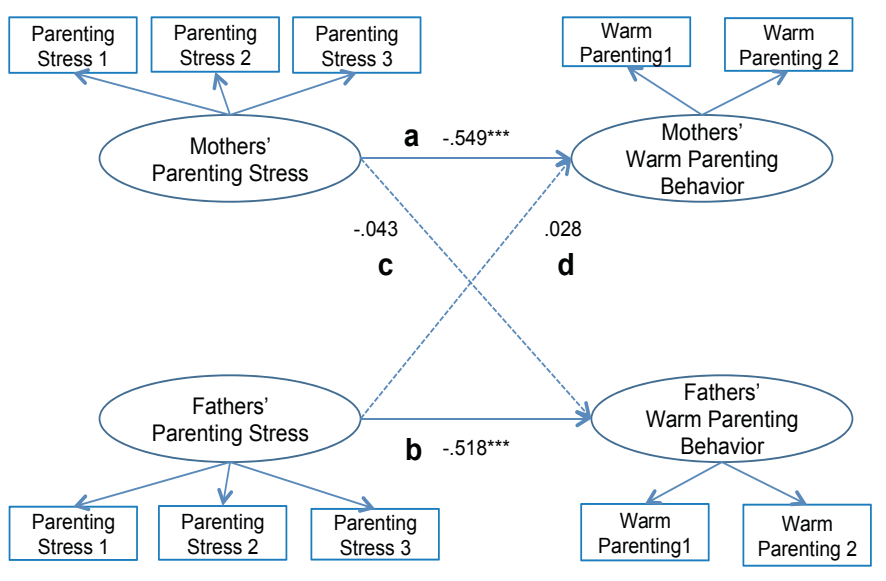

Figure 1. Actor and partner effects of mothers' and fathers' parenting stress on warm parenting behavior (standardized regression coefficients).

${ }^{* * *} p<.001$.

첫째, 양육스트레스가 온정적 양육행동에 미치는 어머니와 아버지의 자기효과는 통계적으로 유의한 차이가 없었다. 둘 째, 양육스트레스가 온정적 양육행동에 미치는 어머니와 아 버지의 상대방효과 역시 유의한 차이가 없었다. 셋째, 어머니 의 온정적 양육행동에 미치는 양육스트레스의 자기효과 $(\beta=$ -.549)와 상대방효과 $(\beta=.028)$ 간에는 통계적으로 유의한 차이 가 있었다. 즉, 어머니의 양육스트레스가 높을수록 이는 자신 의 온정적 양육행동에 부적으로 유의한 영향을 미친 반면, 아 버지의 양육스트레스는 어머니의 온정적 양육행동에 유의미 한 영향을 미치지 않았다. 넷째, 아버지의 온정적 양육행동에 미치는 양육스트레스의 자기효과 $(\beta=-.518)$ 와 상대방효과 $(\beta$ $=-.043$ )간에도 통계적으로 유의한 차이가 있었다. 즉, 아버지 의 양육스트레스가 높을수록 이는 자신의 온정적 양육행동에 부적으로 유의한 영향을 미친 반면, 어머니의 양육스트레스는 아버지의 온정적 양육행동에 유의미한 영향을 미치지 않아 아

Table 2

Differences Between Base and Constrained Models

\begin{tabular}{|c|c|c|c|c|c|c|}
\hline Model & $\chi^{2}$ & $d f$ & TLI & CFI & RMSEA & $\chi^{2}$ difference test \\
\hline Base model & 334.791 & 55 & .949 & .964 & .054 & \\
\hline Actor effect constrained $(\mathrm{a}=\mathrm{b})$ & 336.506 & 56 & .949 & .964 & .053 & $\chi^{2}(1)=1.715$ \\
\hline $\begin{array}{l}\text { Constrained for mothers' } \\
\text { warm parenting behavior }(\mathrm{a}=\mathrm{d})\end{array}$ & 411.041 & 56 & .936 & .954 & .060 & $\chi^{2}(1)=76.250^{* * *}$ \\
\hline
\end{tabular}

${ }^{* * *} p<.001$. 
버지 역시 배우자의 양육스트레스보다는 자신의 양육스트레 스가 자신의 온정적 양육행동에 더 큰 영향을 미쳤음을 알 수 있다.

\section{양육스트레스가 가족 응집성과 유연성에 미 치는 자기효과와 상대방효과 검증}

부모의 교육수준과 월 평균 가구소득이 양육스트레스에 미치 는 영향을 통제한 후 양육스트레스가 가족 응집성과 유연성 에 미치는 자기효과와 상대방효과를 검증하였다. 모형의 적 합도는 $\chi^{2}=442.044(d f=55, p<.001), \mathrm{CFI}=.959, \mathrm{TLI}=.941$, $\mathrm{RMSEA}=.059$ 로 나타나 모형이 분석 자료를 적절히 설명하였 다. 부모의 교육수준 $(\beta=-.109, p<.01)$ 과 월 평균 가구소득 $(\beta$ $=-.122, p<.001)$ 은 어머니의 양육스트레스에 유의한 영향을 미쳤으며, 부모의 교육수준 $(\beta=-.118, p<.01)$ 과 월 평균 가구 소득 $(\beta=-.104, p<.01)$ 은 아버지의 양육스트레스에도 유의한 영향을 미쳤다.

Figure 2 와 같이 양육스트레스는 가족 응집성과 유연성에 부적인 영향을 미쳤으며, 자기효과와 상대방 효과 모두 유의 하였다. 양육스트레스의 자기효과와 상대방효과의 크기를 상 대적으로 비교하기 위해 총 4 번의 등가제약 모형을 설정하였 다. 순서대로 설정한 네 번의 등가제약 모형은 위의 양육스트 레스와 온정적 양육행동 간의 과정과 일치하며, 모형의 분석 결과는 Table 3 과 같다.

첫째, 양육스트레스가 가족 응집성과 유연성에 미치는 어 머니와 아버지의 자기효과는 통계적으로 유의한 차이가 없었 다. 둘째, 양육스트레스가 가족 응집성과 유연성에 미치는 어 머니와 아버지의 상대방효과 역시 유의한 차이가 없었다. 셋 째, 어머니의 가족 응집성과 유연성에 미치는 양육스트레스의

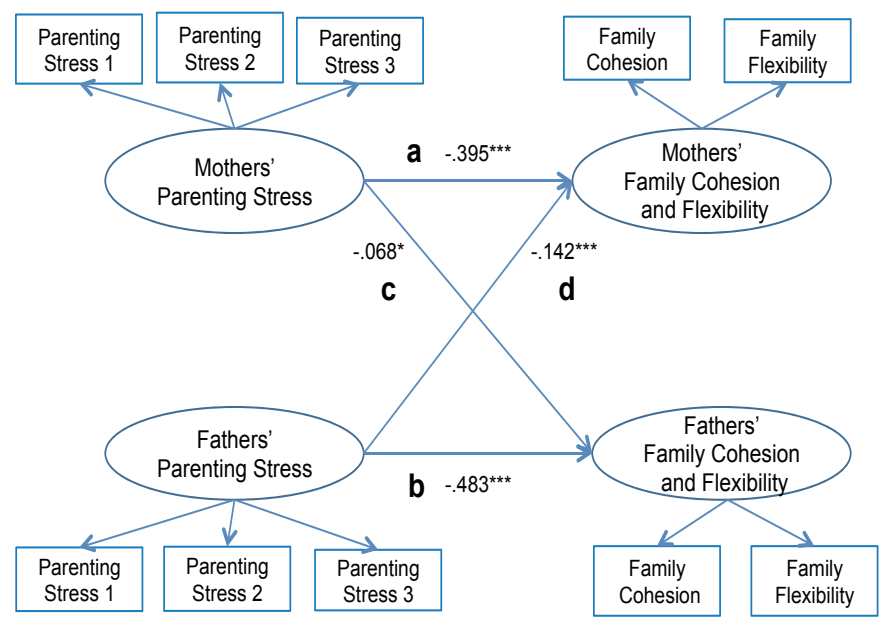

Figure 2. Actor and partner effects of mothers' and fathers' parenting stress on family cohesion and flexibility (standardized regression coefficients).

${ }^{*} p<.05 .{ }^{* * *} p<.001$.

자기효과 $(\beta=-.395)$ 와 상대방효과 $(\beta=-.142)$ 간에는 통계적으 로 유의한 차이가 있었다. 즉, 어머니와 아버지의 양육스트레 스 모두 어머니의 가족 응집성과 유연성에 유의미한 부적 영 향을 미쳤으며, 어머니의 가족 응집성과 유연성에 미치는 자 신의 양육스트레스가 아버지의 양육스트레스보다 더 큼을 확 인할 수 있다. 넷째, 아버지의 가족 기능에 미치는 양육스트레 스의 자기효과 $(\beta=-.068)$ 와 상대방효과 $(\beta=-.483)$ 간에도 통계 적으로 유의한 차이가 있었다. 즉, 어머니와 아버지의 양육스 트레스 모두 아버지의 가족 응집성과 유연성에 부적으로 유의 한 영향을 미쳤으며, 아버지의 가족 응집성과 유연성에 미치 는 영향 역시 배우자보다는 자신의 양육스트레스가 더 컸다.

Table 3

Differences Between Base and Constrained Models

\begin{tabular}{|c|c|c|c|c|c|c|}
\hline Model & $\chi^{2}$ & $d f$ & TLI & CFI & RMSEA & $\chi^{2}$ difference test \\
\hline Base model & 334.791 & 55 & .949 & .964 & .054 & \\
\hline Actor effect constrained $(\mathrm{a}=\mathrm{b})$ & 336.506 & 56 & .949 & .964 & .053 & $\chi^{2}(1)=1.715$ \\
\hline Partner effect constrained $(\mathrm{c}=\mathrm{d})$ & 336.688 & 56 & .949 & .964 & .053 & $\chi^{2}(1)=1.897$ \\
\hline $\begin{array}{l}\text { Constrained for mothers' } \\
\text { warm parenting behavior }(\mathrm{a}=\mathrm{d})\end{array}$ & 411.041 & 56 & .936 & .954 & .060 & $\chi^{2}(1)=76.250^{* * *}$ \\
\hline $\begin{array}{l}\text { Constrained for fathers' } \\
\text { warm parenting behavior }(\mathrm{b}=\mathrm{c})\end{array}$ & 398.206 & 56 & .938 & .956 & .058 & $\chi^{2}(1)=63.415^{* * *}$ \\
\hline
\end{tabular}

${ }^{* * *} p<.001$. 


\section{가족 응집성과 유연성이 온정적 양육행동에 미치는 자기효과와 상대방효과 검증}

가족 응집성과 유연성이 온정적 양육행동에 미치는 자기효과 와 상대방효과를 검증하였다. 모형의 적합도는 $\chi^{2}=239.771$ $(d f=34, p<.001), \mathrm{CFI}=.973, \mathrm{TLI}=.957, \mathrm{RMSEA}=.054$ 로 나 타나 모형이 분석 자료를 적절히 설명하였다. 부모의 교육수 준이 모의 가족 응집성과 유연성 $(\beta=.145, p<.001)$ 및 아버지 의 가족 응집성과 유연성 $(\beta=.163, p<.001)$ 에 유의한 영향을 미쳤으며, 월 평균 가구소득은 유의한 영향을 미치지 않았다.

Figure 3과 같이 모형을 설정한 후 가족 응집성과 유연성이 온정적 양육행동에 미치는 자기효과와 상대방효과를 검증하 였다. 가족 응집성과 유연성은 온정적 양육행동에 정적인 영 향을 미쳤으며, 모든 자기효과와 부분적인 상대방 효과가 유 의하였다. 가족 응집성과 유연성의 자기효과와 상대방효과의 크기를 상대적으로 비교하기 위해 위의 모형과 같이 총 4 번의 등가제약 모형을 순서대로 설정하였으며 모형의 분석 결과는 Table 4와 같다.

첫째, 가족 응집성과 유연성이 온정적 양육행동에 미치는 어머니 $(\beta=.478)$ 와 아버지 $(\beta=.560)$ 의 자기효과는 통계적으 로 유의한 차이가 있었다. 즉, 가족 응집성과 유연성이 온정적 양육행동에 미치는 영향은 아버지에게서 더 큰 것으로 확인 되었다. 둘째, 가족 응집성과 유연성이 온정적 양육행동에 미 치는 어머니와 아버지의 상대방효과는 유의한 차이가 없었다. 셋째, 어머니의 온정적 양육행동에 미치는 가족 응집성과 유 연성의 자기효과 $(\beta=.478)$ 와 상대방효과 $(\beta=.012)$ 간에는 통

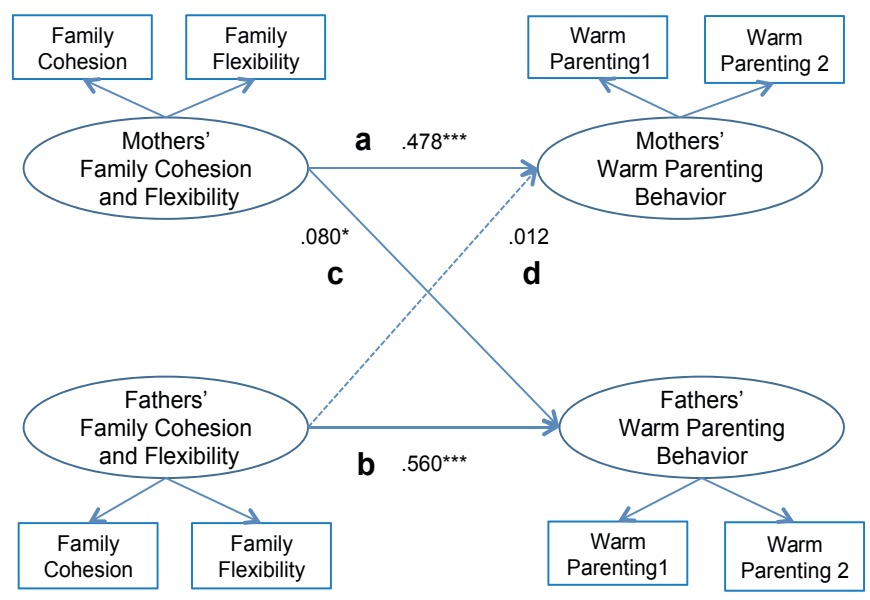

Figure 3. Actor and partner effects of mothers' and fathers' family cohesion and flexibility on warm parenting behavior (standardized regression coefficients). ${ }^{*} p<.05 .{ }^{* * *} p<.001$.
계적으로 유의한 차이가 있었다. 즉, 어머니와 아버지의 가족 응집성과 유연성 모두 어머니의 온정적 양육행동에 정적인 영 향을 미쳤으며, 어머니의 온정적 양육행동에 미치는 자신의 가족 응집성과 유연성이 아버지의 가족 응집성과 유연성보다 더 컸다. 넷째, 아버지의 온정적 양육행동에 미치는 가족 응집 성과 유연성의 자기효과 $(\beta=.560)$ 와 상대방효과 $(\beta=.080)$ 간 에도 통계적으로 유의한 차이가 있었다. 즉, 어머니와 아버지 의 가족 응집성과 유연성 모두 아버지의 가족 응집성과 유연 성에 정적으로 유의한 영향을 미쳤으며, 아버지의 온정적 양 육행동에 미치는 영향 역시 배우자보다는 자신의 가족 응집성 과 유연성이 더 컸다.

\section{가족 응집성과 유연성의 매개효과 검증}

양육스트레스가 온정적 양육행동, 양육스트레스가 가족 응집 성과 유연성, 가족 응집성과 유연성이 온정적 양육행동에 미 치는 효과에 대한 모형이 모두 적합한 것으로 확인되었으므 로 매개효과를 검증하였다. 우선 Figure 4 와 같이 부분 매개모 형을 최종모형으로 설정하고 적합도를 검증하였다. 모형의 적 합도는 $\chi^{2}=576.729(d f=100, p<.001), \mathrm{CFI}=.962, \mathrm{TLI}=.948$, $\mathrm{RMSEA}=.057$ 로 나타나 부분 매개모형이 분석 자료에 적합한

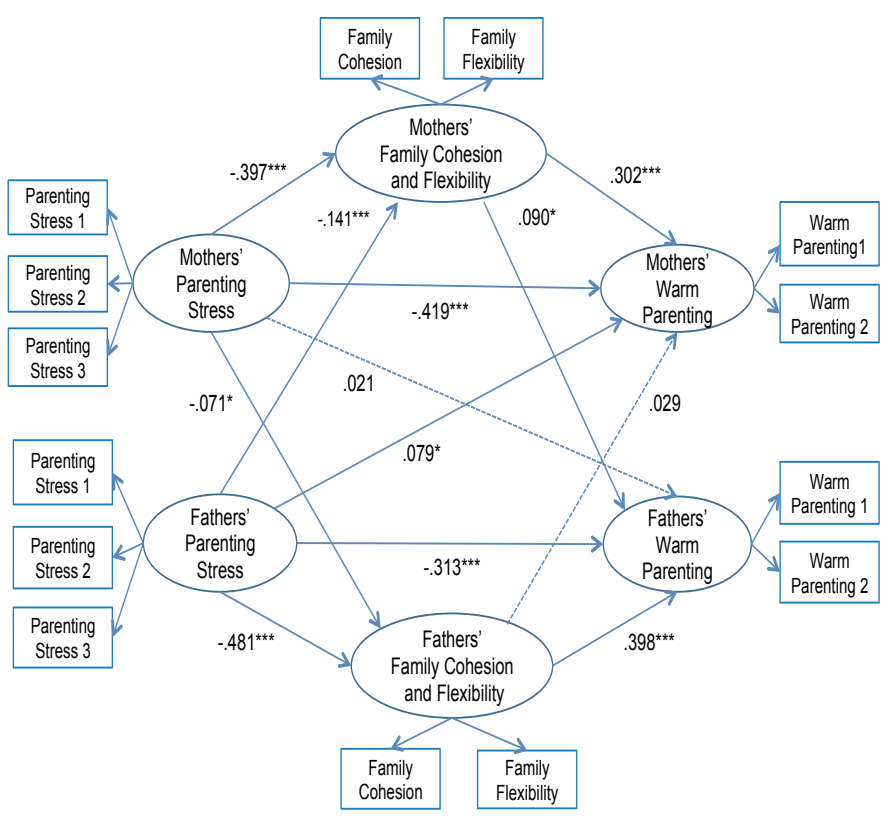

Figure 4. Hypothetical model of actor and partner effects of mothers' and fathers' parenting stress and family cohesion and flexibility on warm parenting behavior(standardized regression coefficients).

${ }^{*} p<.05 .{ }^{* * *} p<.001$. 
Table 4

Differences Between Base and Constrained Models

\begin{tabular}{lcccccc}
\hline \multicolumn{1}{c}{ Model } & $\chi^{2}$ & $d f$ & TLI & CFI & RMSEA & $\chi^{2}$ difference test \\
\hline Base model & 334.791 & 55 & .949 & .964 & .054 & \\
Actor effect constrained $(\mathrm{a}=\mathrm{b})$ & 336.506 & 56 & .949 & .964 & .053 & $\chi^{2}(1)=1.715$ \\
$\begin{array}{l}\text { Partner effect constrained }(\mathrm{c}=\mathrm{d}) \\
\text { Constrained for mothers }\end{array}$ & 336.688 & 56 & .949 & .964 & .053 & $\chi^{2}(1)=1.897$ \\
$\quad$ warm parenting behavior $(\mathrm{a}=\mathrm{d})$ & 411.041 & 56 & .936 & .954 & .060 & $\chi^{2}(1)=76.250^{* * *}$ \\
$\begin{array}{l}\text { Constrained for fathers' } \\
\quad \text { warm parenting behavior }(\mathrm{b}=\mathrm{c})\end{array}$ & 398.206 & 56 & .938 & .956 & .058 & $\chi^{2}(1)=63.415^{* * *}$ \\
\hline
\end{tabular}

${ }^{* * *} p<.001$.

것으로 나타났다. 그러나 어머니의 양육스트레스가 아버지의 온정적 양육행동에 미치는 직접경로와 아버지의 가족 응집성 과 유연성이 어머니의 온정적 양육행동에 미치는 직접경로가 통계적으로 유의하지 않았다. 이에 따라 Martens (2005)의 제 안대로 두 개의 경로를 제거한 수정모형을 경쟁모형으로 설정 하여 $\chi^{2}$ 차이검증을 실시하였다.

수정모형의 적합도는 $\chi^{2}=577.553(d f=102, p<.001), \mathrm{CFI}=$ $.962, \mathrm{TLI}=.950, \mathrm{RMSEA}=.056$ 으로 분석 자료에 적합하였다. $\chi^{2}$ 차이검증 결과에 따라 가설모형과 수정모형 간에 통계적으

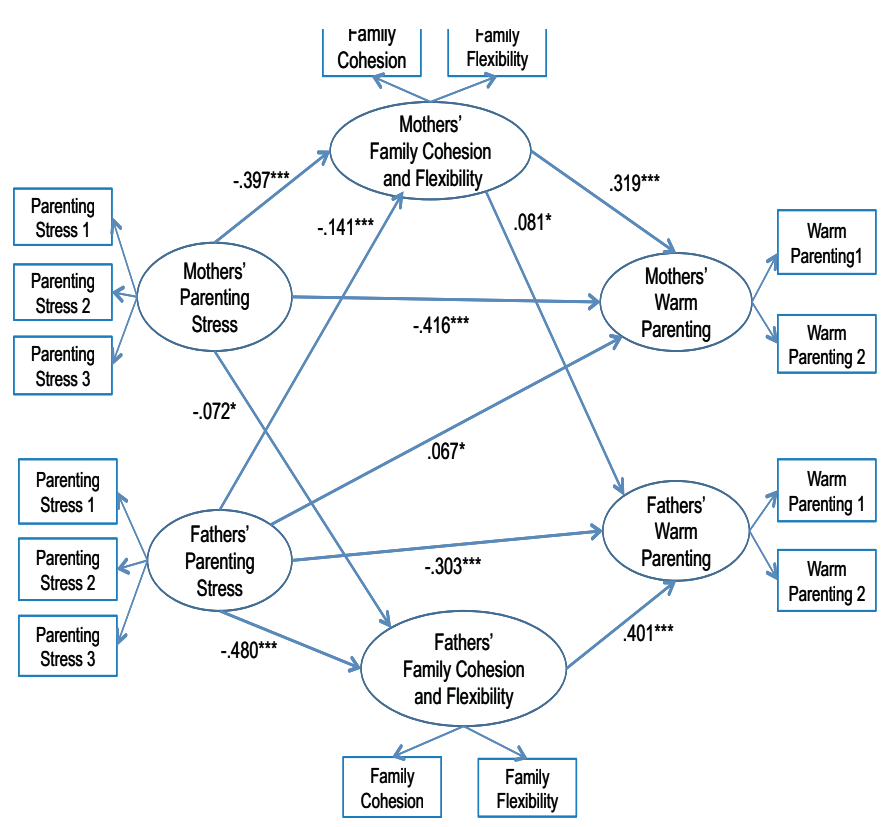

Figure 5. Final model of actor and partner effects of mothers' and fathers' parenting stress and family cohesion and flexibility on warm parenting behavior (standardized regression coefficients).

${ }^{*} p<.05 .{ }^{* * *} p<.001$.
로 유의한 차이가 없는 것 $\left(\chi^{2}[d f=2]=.824, p>.05\right)$ 을 확인 한 후 간명성의 원리에 따라 더 간명한 수정모형을 최종 모형으 로 선택하였다.

다음으로 최종모형의 매개효과를 검증하기 위하여 Sobel 검증(Baron \& Kenny, 1986)을 실시였으며, 구체적인 분석 결 과는 Table 5와 같다. 먼저 어머니와 아버지 모두 양육스트레 스가 온정적 양육행동에 미치는 직접 자기효과가 통계적으로 유의하였다. 다음으로 최종모형에 존재하는 총 6개의 직, 간접 경로 모두 통계적으로 유의하게 나타났다. 첫째, 간접 자기효 과 모두 유의하여 어머니와 아버지 모두의 양육스트레스가 자 신의 가족 응집성과 유연성을 거쳐 자신의 온정적 양육행동에 미치는 간접 자기효과는 모두 통계적으로 유의하였다. 둘째, 간접 상대방효과 4 개 경로의 유의미한 영향을 확인하였다. 아 버지의 양육스트레스가 어머니의 가족 응집성과 유연성을 거 쳐 어머니의 온정적 양육행동에 미치는 간접 상대방효과와 어 머니의 양육스트레스가 어머니 및 아버지의 가족 응집성과 유 연성을 거쳐 아버지의 온정적 양육행동에 미치는 두 개의 간 접 상대방효과 역시 통계적으로 유의하였다. 또한 아버지의 양육스트레스가 어머니의 가족 응집성과 유연성을 거쳐 아버 지의 온정적 양육행동에 미치는 간접 상대방효과 역시 통계적 으로 유의하였다.

\section{논의 및 결론}

본 연구는 유아를 둔 부모의 양육스트레스가 온정적 양육행동 에 미치는 관계를 살펴보고, 두 변인 사이에 가족 응집성과 유 연성이 매개역할을 하는지 탐색하였다. 연구 결과를 요약 및 논의하면 다음과 같다. 첫째, 양육스트레스와 온정적 양육행 동의 관계에서 어머니와 아버지 모두 자신의 양육스트레스가 
Table 5

Direct, Indirect, and Total Effects Among Variables

\begin{tabular}{|c|c|c|c|c|c|}
\hline & & & Path & $B(\beta)$ & $\begin{array}{l}\text { Sobel Test } \\
(z)\end{array}$ \\
\hline \multirow[t]{2}{*}{$\begin{array}{l}\text { Direct } \\
\text { effect }\end{array}$} & $\begin{array}{l}\text { Actor } \\
\text { effect }\end{array}$ & M & Parenting stress $(\mathrm{M}) \longrightarrow$ Warm parenting behavior $(\mathrm{M})$ & $-.368(-.419)^{* * *}$ & - \\
\hline & & $\mathrm{F}$ & Parenting stress $(\mathrm{F}) \rightarrow$ Warm parenting behavior $(\mathrm{F})$ & $-.345(-.313)^{* * *}$ & - \\
\hline \multirow[t]{5}{*}{$\begin{array}{l}\text { Indirect } \\
\text { effect }\end{array}$} & $\begin{array}{l}\text { Actor } \\
\text { effect }\end{array}$ & M & $\begin{array}{l}\text { Parenting stress }(\mathrm{M}) \rightarrow \text { Family cohesion and flexibility }(\mathrm{M}) \\
\rightarrow \text { Warm parenting behavior }(\mathrm{M})\end{array}$ & $-.105(-.120)^{* * *}$ & -6.276 \\
\hline & & $\mathrm{F}$ & $\begin{array}{l}\text { Parenting stress }(\mathrm{F}) \rightarrow \text { Family cohesion and flexibility }(\mathrm{F}) \\
\rightarrow \text { Warm parenting behavior }(\mathrm{F})\end{array}$ & $-.211(-.191)^{* * *}$ & -8.090 \\
\hline & $\begin{array}{l}\text { Partner } \\
\text { effect }\end{array}$ & M & $\begin{array}{l}\text { Parenting stress }(\mathrm{F}) \rightarrow \text { Family cohesion and flexibility }(\mathrm{M}) \\
\rightarrow \text { Warm parenting behavior }(\mathrm{M})\end{array}$ & $-.040(-.043)^{* * *}$ & -2.147 \\
\hline & & $\mathrm{F}$ & $\begin{array}{l}\text { Parenting stress }(\mathrm{M}) \rightarrow \text { Family cohesion and flexibility }(\mathrm{M}) \\
\rightarrow \text { Warm parenting behavior }(\mathrm{F})\end{array}$ & $-.036(-.036)^{*}$ & -2.147 \\
\hline & & & $\begin{array}{l}\text { Parenting stress }(\mathrm{F}) \rightarrow \text { Family cohesion and flexibility }(\mathrm{M}) \\
\rightarrow \text { Warm parenting behavior }(\mathrm{F})\end{array}$ & $-.014(-.013)^{*}$ & -1.988 \\
\hline \multirow[t]{4}{*}{ Total effect } & & M & Parenting stress $(\mathrm{M}) \rightarrow$ Warm parenting behavior $(\mathrm{M})$ & $-.471(-.537)^{* * *}$ & - \\
\hline & & & Parenting stress $(\mathrm{F}) \rightarrow$ Warm parenting behavior $(\mathrm{M})$ & $.035(.036)^{* * *}$ & - \\
\hline & & $\mathrm{F}$ & Parenting stress $(\mathrm{F}) \longrightarrow$ Warm parenting behavior $(\mathrm{F})$ & $-.563(-.508)^{* * *}$ & - \\
\hline & & & Parenting stress $(\mathrm{M}) \rightarrow$ Warm parenting behavior $(\mathrm{F})$ & $-.507(-.056)^{* * *}$ & - \\
\hline
\end{tabular}

Note. $\mathrm{M}=$ mother; $\mathrm{F}=$ father.

${ }^{*} p<.05 .{ }^{* * *} p<.001$.

자신의 온정적 양육행동에 부적인 영향을 미치는 자기효과만 나타나고 상대방효과는 없었다. 모형 간 효과 크기의 상대적 비교 결과, 어머니와 아버지의 자기효과와 상대방효과의 크기 는 통계적으로 유의한 차이가 없었다. 또한 어머니와 아버지 모두 온정적 양육행동은 상대방의 양육스트레스보다 자신의 양육스트레스로부터 더 큰 영향을 받았다. 이는 부모가 지각 하는 양육스트레스가 자신의 온정적 양육행동에 부적인 영향 을 미친다는 선행연구(Abidin, 1992; Ponnet et al., 2013)를 뒷받 침하는 결과이다. 즉, 부모가 지각한 양육스트레스가 부정적 심리상태를 유발한 것(Kanner et al., 1981; Zhang et al., 2016) 으로 양육 상황에서 촉발된 부정적 인지-정서 처리과정이 결 국 온정적이지 않은 양육행동으로 전이된 결과(Pinderhughes, Dodge, Bates, Pettit, \& Zelli, 2000)라고 해석할 수 있다.

더불어 주 양육자인 어머니뿐만 아니라 아버지에게서도 자 신이 지각하는 양육스트레스와 온정적 양육행동 간에 부적 영 향이 동일하게 나타나는 것은 아버지의 양육 참여가 증가하고
있는 현 상황에서 이들이 과거보다 더 높은 수준의 양육스트 레스를 받음을 반영한 것이라 볼 수 있다. 가정 내에서 남성의 역할은 여성의 역할보다 뚜렷하게 구별되지 않아서(Ponnet et al., 2013) 아버지가 가정 내에서 지각하는 양육 역할이 어머니 보다 적을 수는 있으나 이들이 느끼는 스트레스나 부정적 심 리 상태와 같은 영향에는 여전히 민감할 것이다. 양육스트레 스에 반응하는 정도가 어머니와 아버지 모두에게서 비슷한 패 턴을 보인다는 선행연구(Deater-Deckard \& Scarr, 1996)를 근 거로 아버지의 역할을 고민해 볼 수 있다. 즉, 아버지의 양육참 여를 단지 어머니의 양육방식을 지원해줌을 넘어서 아버지 자 신의 개인 발달을 높이고, 결과적으로 온정적인 양육행동으로 이끌 수 있도록 도와야할 것이다. 이를 위해 양육 환경에서 아 버지가 지각하는 긍정적 심리특성을 높이고, 부정적인 상황으 로부터 보호하고 예방할 수 있는 방안을 고려해야 할 필요가 있다.

둘째, 양육스트레스와 가족 응집성과 유연성 관계에서 어 
머니와 아버지 모두 양육스트레스가 가족 응집성과 유연성에 부적인 영향을 미쳤으며, 자기효과와 상대방효과가 모두 나타 났다. 즉, 어머니와 아버지 자신의 양육스트레스는 자신의 가 족 응집성과 유연성에 부적인 영향을 미쳤을 뿐만 아니라 어 머니의 양육스트레스는 아버지의 가족 응집성과 유연성에, 아 버지의 양육스트레스 역시 어머니의 가족 응집성과 유연성에 부적인 영향을 미쳐 상대방효과가 확인되었다. 그러나 어머니 와 아버지의 자기효과와 상대방효과의 크기는 통계적으로 유 의한 차이가 없었다.

이와 같은 결과를 위의 양육스트레스와 양육행동과의 관계 와 비교해서 설명할 필요가 있다. 즉, 양육스트레스가 자신의 온정적 양육행동에 부적인 영향을 미쳤으나 상대방효과의 크 기는 통계적으로 유의한 차이가 없었음을 밝힌 위의 결과는 상호 밀접한 부부 간의 관계에서 배우자의 심리적 스트레스가 상대방의 양육행동에 영향을 미친다는 선행연구(Ponnet et al., 2013; Zhang et al., 2016)와 일치하지 않는 결과이다. 이와 반대 로 배우자의 양육스트레스는 자신의 가족 응집성과 유연성에 유의한 영향을 미쳐 상대방 효과를 확인할 수 있었다. 이는 얼 마나 가족이 응집되고, 유연하여 기능적 역할을 하는지에 대 한 자기 인식과 양육 환경에서 본인이 실질적인 행동을 수행 함에 있어 나타나는 행동 간에 자기 보고의 차이에서 기인한 것이라 유추해 볼 수 있다. 다시 말해 본 연구에서 양육스트레 스로 대변되는 부부의 심리적 특성이 자신의 행동보다 인식과 더 밀접한 관련이 있고, 이에 따라 자기 보고에 있어서도 인식 보다 행동의 영역이 더 객관적으로 측정될 수 있었기 때문이 라 해석할 수 있다.

다음으로 어머니와 아버지 모두에게 가족 응집성과 유연성 은 상대방의 양육스트레스로부터 영향을 받았다. 이는 배우 자의 양육스트레스가 높을수록 자신이 지각하는 가족 응집성 이 유의미하게 낮음을 보고한 선행연구의 결과(Mitchell et al., 2016)를 지지하는 것이다. 이를 바탕으로 양육스트레스를 낮 추고 가족 구성원 간의 상호작용이 원활하게 이루어질 수 있 도록 부모가 함께 상담 또는 의사소통 훈련에 적극적으로 참 여하여 가족이 기능적 역할을 하도록 해야 할 것이다. 그러나 양육스트레스와 가족 응집성과 유연성 간의 자기효과 및 상대 방효과에 대한 연구가 부족하다는 점을 고려할 때 추후의 연 구를 통해 두 변인 간의 관계에 대한 점검이 필요하다.

셋째, 가족 응집성과 유연성과 온정적 양육행동의 관계에 서는 어머니와 아버지 모두 자신이 지각한 가족 응집성과 유 연성이 온정적 양육행동에 정적인 영향을 미치는 자기효과가 있었으나 상대방효과는 어머니의 가족 응집성과 유연성이 아
버지의 온정적 양육행동에 미치는 관계에서만 나타났다. 모형 간 효과 크기의 상대적 비교 결과, 자기효과에서만 통계적으 로 유의한 차이가 있었는데 어머니보다 아버지에게서 자신의 가족 응집성과 유연성이 온정적 양육행동에 미치는 영향이 더 컸다. 상대방효과에서는 어머니와 아버지 간에 통계적으로 유 의한 차이가 없었다.

어머니보다 아버지의 가족 응집성과 유연성이 온정적 양육 행동에 더 큰 영향을 미치는 것으로 나타난 것은 아버지의 경 우 가정이 기능적으로 운영되고 있다고 지각할수록 즉, 가족 구성원으로부터 더 높은 수준의 지지를 받을수록 아버지의 양 육참여로의 효율적인 전이가 가능하였기 때문이라고 볼 수 있 다. 건강한 가정은 건강한 사회를 만드는데 중추적인 역할을 한다. 가정 내에서 모든 가족 구성원은 가족이 처하는 삶의 다 양한 문제를 함께 고민하고 해결하여 적절한 합의점을 찾는 과정이 요구되며, 이는 양육 환경에서의 어려움을 해결하는 데에도 똑같이 적용된다. 따라서 한 가정이 올바르게 기능하 는 것은 아버지가 자녀를 양육함에 있어서 보다 긍정적인 접 근이 가능하도록 도울 것이다. 가정 내 돌봄 및 참여에 대한 아 버지의 역할의 중요성이 점차 커짐에 따라 어머니와 분리되는 아버지의 고유한 역할을 알고 이를 효율적으로 수행할 수 있 도록 적절한 교육 프로그램의 도입이 필요하다.

마지막으로 양육스트레스가 온정적 양육행동에 미치는 영 향을 가족 응집성과 유연성이 매개하는지 확인하였다. 먼저 어머니와 아버지 모두에게 자신의 양육스트레스가 자신의 온 정적 양육행동에 직접적인 부적 영향을 미쳐 양육스트레스가 높을수록 온정적 양육행동이 낮아지는 직접효과를 보였다. 또 한 어머니와 아버지 모두에게서 자신의 양육스트레스는 자신 의 가족 응집성과 유연성을 매개로 자신의 온정적 양육행동에 부적인 영향을 미치는 자기효과의 간접효과를 확인하였다. 흥 미롭게도 어머니의 양육스트레스는 어머니 및 아버지의 가족 응집성과 유연성을 매개로 아버지의 온정적 양육행동에 부적 인 영향을 미쳤으나 아버지의 양육스트레스는 어머니의 가족 응집성과 유연성만을 매개로 하여 어머니 및 아버지의 온정적 양육행동에 부적인 영향을 미쳐 상대방효과의 간접효과를 확 인하였다. 본 연구에서는 자기효과 및 상대방효과의 간접효과 가 어머니와 아버지 각자에게서 다른 경로로 나타났다. 양육 스트레스, 온정적 양육행동 및 가족 응집성과 유연성과의 관 계에서 자기효과 및 상대방효과를 통합적으로 면밀하게 살펴 본 연구가 드물어 이러한 결과를 뒷받침하는데 한계가 있다. 그러나 이는 전반적으로 유아기 자녀를 둔 가정의 남편과 아 내의 양육스트레스가 낮을수록 자신의 부모 역할에 대한 만족 
과 자신감이 증대되며, 긍정적인 가족의 기능이 높아짐을 시 사하는 결과로 온정적 양육행동을 이끌기 위해서는 양육스트 레스를 낮추고, 가족 응집성과 유연성의 수준을 높이기 위한 노력이 함께 요구된다 할 수 있다. 또한 건강한 가정의 운영과 자녀의 긍정적 양육발달을 도모하는 온정적 양육행동을 높이 는 교육 및 개입 프로그램 개발 시 도움이 될 수 있다는데 실제 적 의의가 있다.

본 연구는 양육스트레스와 온정적 양육행동의 관계에서 가 족 응집성과 유연성의 구체적인 매커니즘을 통합적으로 고려 하여 살펴보았다. 특히, 쌍으로 이루어진 두 명의 구성원을 짝 자료의 측정 타당성을 반영할 수 있는 분석 방법을 활용하여 보다 정확한 결과를 도출할 수 있었다. 또한 선행연구에서 제 시한 해당 변인의 어머니와 아버지 각각의 개별적인 영향력을 넘어서 서로 간 상호 영향력을 자기효과 비교, 상대방효과 비 교 및 자기효과와 상대방효과 간에 비교를 통해 검증했다는 데 의의가 있다. 그러나 본 연구는 제한점은 다음과 같다. 첫째 본 연구는 학령기로의 전이를 앞둔 유아 후기 자녀를 둔 부모 를 대상으로 자기효과와 상대방효과를 확인했기 때문에 결과 를 일반화시키기에는 한계가 있다. 자녀의 연령을 세분화하여 다양한 연령의 자녀를 둔 부모를 대상으로 연구가 진행될 필 요가 있으며, 횡단 연구의 검증을 넘어서 변인 간 연속된 종단 적 추이를 탐색하는 것도 의의가 있을 것이다. 둘째, 양육스트 레스, 가족 응집성과 유연성 및 온정적 양육행동과 관련이 높 은 부모의 심리.정서적 특성을 함께 고려하지 못했다. 추후 연 구에서는 양육과 관련이 높은 어머니와 아버지의 자아존중감, 양육효능감, 우울 등과 같은 특성을 포함시켜 변인 간의 구조 적 관계를 보다 다양한 측면에서 살펴보고, 궁극적으로 자녀 의 발달에 어떠한 영향을 미치는지 확인해 볼 필요가 있다. 마 지막으로 본 연구에서의 모든 변인은 패널 연구에서 조사된 어머니 및 아버지의 설문보고만이 분석에 사용되었다. 후속 연구에서 이를 보완하기 위해 객관적인 관찰이나 면담과 같은 질적 자료를 추가한다면 변인 간의 구조를 이해하고 효과를 검증함에 있어 보다 폭넓은 이해가 가능할 것이다.

\section{Notes}

This article was presented as a poster at the 2016 Annual Spring Conference of the Korean Association of Child Studies.

\section{Conflict of Interest}

No potential conflict of interest relevant to this article was reported.

\section{References}

\section{In English}

Abidin, R. R. (1992). The determinants of parenting behavior. Journal of Clinical Child Psychology, 21(4), 407-412. doi:10.1207/s15374424jccp2104_12

Baron, R. M., \& Kenny, D. A. (1986). The moderator-mediator variable distinction in social psychological research: Conceptual, strategic, and statistical considerations. Journal of Personality and Social Psychology, 51(6), 1173-1182. doi:10.1037/0022-3514.51.6.1173

Cook, W. L., \& Kenny, D. A. (2005). The actor-partner interdependence model: A model of bidirectional effects in developmental studies. International Journal of Behavioral Development, 29(2), 101-109. doi:10.1080/01650250444000405

Deater-Deckard, K., \& Scarr, S. (1996). Parenting stress among dual-earner mothers and fathers: Are there gender differences? Journal of Family Psychology, 10(1), 45-59. doi:10.1037/0893-3200.10.1.45

Hong, S., Malik, M. L., \& Lee, M.-K. (2003). Testing configural, metric, scalar, latent mean invariance across genders in sociotropy and autonomy using a non-western sample. Educational and Psychological Measurement, 63(4), 636-654. doi:10.1177/0013164403251332

Hu, L., \& Bentler, P. M. (1999). Cutoff criteria for fit indexes in covariance structure analysis: Conventional criteria versus new alternatives. Structural Equation Modeling: A Multidisciplinary Journal, 6(1), 1-55. doi:10.1080/10705519909540118

Kanner, A. D., Coyne, J. C., Schaefer, C., \& Lazarus, R. S. (1981). Comparison of two models of stress measurement: Daily hassles and uplifts versus major life events. Journal of Behavioral Medicine, 4(1), 1-39. doi:10.1007/BF00844845

Kenny, D. A. (1996). Models of non-independence in dyadic research. Journal of Social and Personal Relationships, 13(2), 279-294.

Martens, M. P. (2005). The use of structural equation modeling in counseling psychology research. The Counseling Psychologist, 33(3), 269-298. doi:10.1177/0011000004272260

Matejevic, M., \& Jovanovic, D. (2014). How students estimate family relationships and competent parenting. ProcediaSocial and Behavioral Sciences, 149(5), 547-552. 
doi:10.1016/j.sbspro.2014.08.208

Mitchell, D. B., \& Hauser-Cram, P. (2009). Early predictors of behavior problems: Two years after early intervention. Journal of Early Intervention, 32(1), 3-16. doi:10.1177/1053815109349113

Mitchell, D. B., Szczerepa, A., \& Hauser-Cram, P. (2016). Spilling over: Partner parenting stress as a predictor of family cohesion in parents of adolescents with developmental disabilities. Research in Developmental Disabilities, 49-50, 258-267. doi:10.1016/j.ridd.2015.12.007

Mulsow, M., Caldera, Y. M., Pursley, M., Reifman, A., \& Huston, A. C. (2002). Multilevel factors influencing maternal stress during the first three years. Journal of Marriage and Family, 64(4), 944-956. doi:10.1111/j.1741-3737.2002.00944.x

Olson, D. H. (2010). FACES-IV manual. Minneapolis, MN: Life Innovations.

Olson, D. H., Gorall, D. M., \& Tiesel, J. W. (2007). FACESIV package: Administration. Minneapolis, MN: Life Innovations.

Olson, D. H., Russell, C. S., \& Sprenkle, D. H. (1983). Circumplex model of marital and family systems: IV. Theoretical update. Family Process, 22(1), 69-83. doi:10.1111/j.15455300.1983.00069.x

Pinderhughes, E. E., Dodge, K. A., Bates, J. E., Pettit, G. S., \& Zelli, A. (2000). Discipline responses: Influences of parents' socioeconomic status, ethnicity, beliefs about parenting, stress, and cognitive-emotional processes. Journal of Family Psychology, 14(3), 380-400. doi:10.1037/0893-3200.14.3.380

Ponnet, K., Mortelmans, D., Wouters, E., Leeuwen, K. V., Bastaits, K., \& Pasteels, I. (2013). Parenting stress and marital relationship as determinants of mothers' and fathers' parenting. Personal Relationships, 20(2), 259-276. doi:10.1111/j.14756811.2012.01404.x

Raikes, H. A., \& Thompson, R. A. (2005). Efficacy and social support as predictors of parenting stress among families in poverty. Infant Mental Health Journal, 26(3), 177-190. doi:10.1002/imhj.20044

Seginer, R., Vermulst, A., \& Gerris, J. (2002). Bringing up adolescent children: A longitudinal study of parents' child-rearing stress. International Journal of Behavioral Development, 26(5), 410422. doi:10.1080/01650250143000355

Shigeto, A., Mangelsdorf, S. C., \& Brown, G. L. (2014). Roles of family cohesiveness, marital adjustment, and child temperament in predicting child behavior with mothers and fathers. Journal of Social and Personal Relationships, 31(2), 200-220. doi:10.1177/0265407513490586

Silver, E. J., Heneghan, A. M., Bauman, L. J., \& Stein, R. E. K. (2006). The relationship of depressive symptoms to parenting competence and social support in inner-city mothers of young children. Maternal and Child Health Journal, 10(1), 105-112. doi:10.1007/s10995-005-0024-4
Zhang, C., Cubbin, C., \& Ci, Q. (2016). Parenting stress and mother-child playful interaction: The role of emotional support. Journal of Family Studies, 1-15. doi:10.1080/1322 9400.2016 .1200113

\section{In Korean}

Cho, B., Lee, J., Lee, H., \& Kwon, H. (1999). Dimensions and assessment of Korean parenting style. Family and Environment Research, 37(10), 123-133. Retrieved from http://www.riss.kr/link?id=A7546387

Choi, H.-S., \& Yeon, E.-M. (2014). Actor and partner effect of infant-parents' psychological characteristics, parenting stress, and positive parenting attitude. Early Childhood Education Research \& Review, 18(6), 5-30. Retrieved from http://www.riss.kr/link?id=A100266797

Eom, E.-J., Park, B.-K., Doh, H.-S., \& Nichiwaki, R. (2014). The relationships between parenting stress, parenting sense of competence, and parenting behavior in Korean and Japanese mothers of early school-aged children. Korean Journal of Child Studies, 35(3), 93-118. doi:10.5723/ KJCS.2014.35.3.93

Kim, G. Y., \& Shin, H. Y. (2013). A study on variables related to paternal parenting behavior: Father involvement, parenting stress, and parenting self-efficacy. Journal of Korean Child Care and Education, 9(2), 191-213. Retrieved from http:// www.riss.kr/link?id=A99623170

Kim, K. H., \& Kang, H. K. (1997). Development of the parenting stress scale. Family and Environment Research, 35(5), 141 150. Retrieved from http://www.riss.kr/link?id=A75471534

Ko, J. J., \& Kim, G. S. (2000). The influence of family adaptability and cohesion on marriage satisfaction and distress of married couples. Family and Environment Research, 38(10), 1-14. Retrieved from http://www.riss.kr/link?id=A75464259

Korea Institute of Child Care and Education. (2013). Panel study on Korean children 2013 (wave 6) assessment profiles [Data file and code book]. Retrieved from http://panel.kicce.re.kr

Lee, I. J. (2015). The effect of parenting involvement of fathers on marital satisfaction in dual earner couples with early childhood children. Korean Journal of Social Welfare Studies, 46(1), 343-370. Retrieved from http://www.riss.kr/ link?id=A100425180

Song, J. J. (2015). SPSS/AMOS statistics analysis method when writing thesis. Paju: 21 Century Books.

Statistics Korea. (2015). Korean social trends 2015. Retrieved from http://kostat.go.kr

Yeon, E.-M., \& Choi, H. (2015). Actor and partner effect of infantparents' emotional value of children, parenting stress, and marital satisfaction. Korea Journal of Child Care and Education, 90, 79-108. Retrieved from http://www.riss.kr/ 
link?id=A100281848

Yeon, E.-M., Yoon, H. O., \& Choi, H. (2016). The structural relationship among parent's perceived depression, family functioning, parenting attitude and internalizing and externalizing problem behaviors of children: Focusing on actor and partner effect. Korean Journal of Early Childhood Education, 36(2), 243-269. Retrieved from http://www. riss.kr/link?id=A101881560

\section{ORCID}

Yea-Ji Hong http://orcid.org/0000-0003-4183-5373

Soon-Hyung Yi http://orcid.org/0000-0002-3381-1788

Received October 29, 2016

Revision received January 9, 2017

Accepted January 26, 2017 